\title{
Bicycle helmet use among American children, 1994
}

Jeffrey J Sacks, Marcie-jo Kresnow, Barbara Houston, Julie Russell

\begin{abstract}
Objective-To estimate ownership and use of bicycle helmets among children in the US in 1994.
\end{abstract}

Methods-As part of a 1994 national telephone survey of 5238 randomly dialed households, adult respondents reported data on bicycle helmet ownership and helmet use among 1645 child bicyclists. Data were weighted to provide national estimates.

Results-It is estimated that $72 \cdot 7 \%$ of children 5-14 year olds ride bicycles, that is, 27.7 million child bicyclists. Of the bicyclists, $50 \cdot 2 \%$ have a helmet and $25.0 \%$ reportedly always wore their helmet when cycling. Reported helmet ownership and use increased with income and educational level and decreased with age. Among regions of the US, those with the highest proportion of states with helmet use laws in 1994 also had the highest proportion of helmet use among children. Among child bicyclists who had been seen by a health care provider in the preceding 12 months, $43.9 \%$ of those counseled to wear a bicycle helmet were reported to comply compared with $19 \cdot 1 \%$ of those seen by a provider but not so counseled (p<0.001).

Division of

Unintentional Injury Prevention, National Center for Injury Prevention and Control (NCIPC), Centers for Disease Control and Prevention, Atlanta, Georgia, USA

JJ Sacks

J Russell

Office of Statistics and Programming, NCIPC, US Department of Health and Human Services, US Public Health

Service, Centers for Disease Control and Disease Control and
Prevention, Atlanta, Georgia, USA

$M$-j Kresnow

B Houston

Correspondence to: Dr Jeffrey J Sacks, National Center for Injury Prevention and Control, Centers for

Disease Control and

Prevention, 4770 Buford

Highway, NE (K-63),

Atlanta, GA 30341, USA.
Conclusions-To meet the year 2000 objective of $50 \%$ of bicyclists wearing helmets, use among American children will have to double. Concerted and increased efforts to promote the wearing of bicycle helmets are necessary.

(Injury Prevention 1996; 2: 258-262)

Keywords: bicycles, helmets.

Bicycle riding, a common activity of American children, causes substantial morbidity and mortality. In particular, head injury is the most common cause of death and serious disability from bicycle related crashes. ${ }^{1-3}$ Bicycle crashes cause an average of 247 traumatic brain injury deaths and 140000 head injuries each year in the US among persons younger than 20 years. ${ }^{4}$ Indeed, bicycle related head injuries are a problem in many parts of the world. ${ }^{5-7}$

Because bicycle safety helmets substantially reduce the risk of head injury, ${ }^{8-11}$ a year 2000 goal for the US is for $50 \%$ of bicyclists to wear helmets. ${ }^{12}$ The most recent national survey for helmet usage, performed in 1991, estimated that only $11.7 \%$ of American children under 15 years wore helmets 'always' or 'almost always' when riding a bicycle. ${ }^{13}$ A 1993 survey targeting ninth through 12 th graders found that helmet usage rates were much lower among adolescents; although $75 \%$ of these students had ridden a bicycle within the year, $93 \%$ reported rarely or never wearing a helmet. ${ }^{14}$ It is estimated that as many as 184 deaths and 116000 head injuries might be prevented annually if all child and adolescent bicyclists wore helmets. ${ }^{4}$

In 1994, the Centers for Disease Control and Prevention conducted the Injury Control and Risk Survey (ICARIS), a national survey designed to assess a wide variety of injury risk factors. This report summarizes data from that survey about bicycle helmet ownership and use among American children in 1994.

\section{Methods}

We conducted a random digit dial telephone survey from 28 April through 18 September 1994. From a listing of all exchanges in all 50 states and the District of Columbia, we stratified telephone exchanges by whether they had $\geqslant 10 \%$ of households occupied by minorities. Such exchanges were sampled at a higher rate than the others. At least six attempts were made to contact each number.

To ensure equal numbers of male and female respondents, once a household was reached, we determined the number of adult (aged 18 years and older) men and women residing there. Using a random procedure, we then selected one gender category from those applicable to the household; if more than one eligible individual was in the gender category, we asked for the individual with the most recent birthday. If a household member agreed to participate, an English or Spanish speaking adult respondent reported on household and individual factors, such as total pretax household income and highest educational level. After enumeration of the age and sex of children under the age of 15 years, respondents were asked, for each child between age 5 and 14, if the child had ridden a bicycle in the preceding 30 days. For each child who had ridden, the respondent was asked if the child had a bicycle helmet, and if yes, how often the child wore a helmet while riding during the preceding 30 days (always, more than half the time, half the time, less than half the time, never). For answers of 'no' to helmet ownership, respondents were asked why the child didn't own a helmet. For answers of usage 
half the time or less, respondents were asked why the child didn't wear a helmet more often. In tallying responses about bicycle riding, helmet ownership, and helmet use, 'don't know' and 'refusal' responses were classified as

Table 1 Bicycle riding among American children aged 5-14 years in the preceding month, by demographic characteristic, 1994

\begin{tabular}{|c|c|c|c|c|}
\hline Characteristic & $\begin{array}{l}\text { No in } \\
\text { sample }\end{array}$ & $\begin{array}{l}\text { No of } \\
\text { riders }\end{array}$ & $\begin{array}{l}\text { Weighted No } \\
\text { of riders }\end{array}$ & $\begin{array}{l}\text { Weighted \% } \\
(95 \% \mathrm{CI})\end{array}$ \\
\hline \multicolumn{3}{|c|}{$128(1020102)$} & 27698649 & $72 \cdot 7(70 \cdot 2$ to $75 \cdot 2)$ \\
\hline Boy & 1242 & 904 & 14735247 & $75.6(72.5$ to 78.7$)$ \\
\hline Girl & 1096 & 737 & 12891853 & $69.6(66.2$ to 73.0$)$ \\
\hline \multicolumn{5}{|l|}{ Age (years) } \\
\hline 5 & 237 & 136 & 2329582 & $61.7(54.9$ to 68.5$)$ \\
\hline 6 & 229 & 161 & 2679316 & 73.3 (66.8 to 79.8$)$ \\
\hline 7 & 265 & 200 & 3334301 & $79.3(74.1$ to 84.5$)$ \\
\hline 8 & 243 & 197 & 3283573 & $83.9(79.2$ to 88.7$)$ \\
\hline 9 & 217 & 174 & 2916968 & $81.2(74.7$ to 87.7$)$ \\
\hline 10 & 231 & 179 & 3064839 & $80.9(75.4$ to 86.3$)$ \\
\hline 11 & 226 & 180 & 3053113 & $80.6(74.6$ to 86.6$)$ \\
\hline 12 & 234 & 157 & 2511652 & $68.0(60.9$ to 75.1$)$ \\
\hline 13 & 239 & 146 & 2503684 & $62.3(55.5$ to 69.2$)$ \\
\hline 14 & 222 & 115 & 2021620 & $55.2(47.9$ to 62.4$)$ \\
\hline \multicolumn{5}{|l|}{ Age group (years) } \\
\hline $5-9$ & 1191 & 868 & 14543741 & 76.0 ( 73.0 to 78.9$)$ \\
\hline $10-14$ & 1152 & 777 & 13154908 & $69.4(65.9$ to 72.9$)$ \\
\hline \multicolumn{5}{|l|}{ Household income } \\
\hline$<\$ 20000$ & 553 & 347 & 5389327 & $64.5(59.1$ to 70.0$)$ \\
\hline$\$ 20000-\$ 34999$ & 515 & 366 & 6560224 & $73.8(68.2$ to 79.4$)$ \\
\hline$\$ 35000-\$ 49999$ & 407 & 294 & 5304418 & $74.8(69.4$ to 80.1$)$ \\
\hline$\geqslant \$ 50000$ & 674 & 502 & 8136720 & $77.0(72.8$ to 81.2$)$ \\
\hline \multicolumn{5}{|l|}{ Educational levelt } \\
\hline$\leqslant$ HS & 754 & 510 & 8849804 & $71.5(67.1$ to 75.9$)$ \\
\hline$>\mathrm{HS}$ and $<\mathrm{CG}$ & 760 & 534 & 9169485 & $72.5(68.0$ to 76.9$)$ \\
\hline CG & 394 & 298 & 4925382 & $75.4(69.6$ to 81.2$)$ \\
\hline$\geqslant P G$ & 401 & 284 & 4478766 & $73.7(67.9$ to 79.6$)$ \\
\hline \multicolumn{5}{|l|}{ Census region } \\
\hline South & 942 & 639 & 8983554 & $69.8(65.6$ to 74.0$)$ \\
\hline West & 562 & 378 & 5937591 & $70.4(65.5$ to 75.4$)$ \\
\hline Northeast & 368 & 256 & 5264250 & $70.8(64.1$ to 77.6$)$ \\
\hline Midwest & 471 & 372 & 7513254 & $80.3(75.9$ to 84.6$)$ \\
\hline
\end{tabular}

*Total pretax household income; values missing for 136 bicyclists.

+Highest educational level achieved in the household $(\mathrm{HS}=$ high school, CG = college graduate, PG = postgraduate).

$\mathrm{PG}=$ postgraduate).
All associations were significant at $\mathrm{p}<0.01$ (log-likelihood $\chi^{2}$ test) except for educational level. Rows within a characteristic may not add to total because of missing data.

Table 2 Bicycle helmet ownership and use among American children aged 5-14 years in the preceding month, by demographic characteristic, 1994

\begin{tabular}{|c|c|c|c|c|}
\hline Characteristic & $\begin{array}{l}\text { No of } \\
\text { owners }\end{array}$ & $\begin{array}{l}\text { Weighted owner \% } \\
(95 \% \text { CI })\end{array}$ & $\begin{array}{l}\text { No of } \\
\text { users }^{\star}\end{array}$ & $\begin{array}{l}\text { Weighted user } \% \\
(95 \% \text { CI })\end{array}$ \\
\hline $\begin{array}{l}\text { Total } \\
\text { Sex }\end{array}$ & 817 & $50 \cdot 2(46 \cdot 8$ to $53 \cdot 7)$ & 410 & $25.0(22.0$ to $27 \cdot 9)$ \\
\hline $\begin{array}{l}\text { Boy } \\
\text { Girl }\end{array}$ & $\begin{array}{l}476 \\
340\end{array}$ & $\begin{array}{l}53.3(48.9 \text { to } 57.6) \\
47.0(42.4 \text { to } 51.6)\end{array}$ & $\begin{array}{l}232 \\
177\end{array}$ & $\begin{array}{l}25.7(22.0 \text { to } 29.4) \\
24.2(20.4 \text { to } 28 \cdot 1)\end{array}$ \\
\hline \multicolumn{5}{|l|}{ Age (years) } \\
\hline $\begin{array}{l}5 \\
6 \\
7 \\
8 \\
9 \\
10 \\
11 \\
12 \\
13 \\
14\end{array}$ & $\begin{array}{r}76 \\
92 \\
120 \\
99 \\
99 \\
91 \\
79 \\
71 \\
57 \\
33\end{array}$ & $\begin{array}{l}58.2(48.8 \text { to } 67.5) \\
59.6(51.2 \text { to } 68.0) \\
60.4(52.8 \text { to } 68.0) \\
49.9(42.0 \text { to } 57.8) \\
60.1(52.2 \text { to } 68.1) \\
49.7(41.5 \text { to } 57.9) \\
43.3(35.0 \text { to } 51.5) \\
46.8(38.0 \text { to } 55.6) \\
37.6(29.1 \text { to } 46.2) \\
29.6(20.2 \text { to } 39.0)\end{array}$ & $\begin{array}{l}51 \\
55 \\
64 \\
55 \\
46 \\
44 \\
32 \\
29 \\
22 \\
12\end{array}$ & $\begin{array}{l}36.5(27.2 \text { to } 45.9) \\
36.2(27.6 \text { to } 44.8) \\
31.3(24.0 \text { to } 38.6) \\
26.8(19.9 \text { to } 33.7) \\
30.0(22.1 \text { to } 37.9) \\
25.4(18.2 \text { to } 32.6) \\
15.7(10.0 \text { to } 21.5) \\
19.3(12.2 \text { to } 26.4) \\
13.7(7.8 \text { to } 19.6) \\
10.6(4.2 \text { to } 17.1)\end{array}$ \\
\hline \multicolumn{5}{|l|}{ Age group (years) } \\
\hline $10-14$ & 331 & $42.3(37.8$ to 46.7$)$ & 139 & $17.5(14.3$ to $20 \cdot 7)$ \\
\hline \multicolumn{5}{|l|}{ Household income } \\
\hline $\begin{array}{l}<\$ 20000 \\
\$ 20000-\$ 34999 \\
\$ 35000-\$ 49999 \\
\geqslant \$ 50000\end{array}$ & $\begin{array}{l}128 \\
147 \\
133 \\
340\end{array}$ & $\begin{array}{l}36.7(29.7 \text { to } 43.7) \\
41.7(34.3 \text { to } 49.0) \\
44.0(36.2 \text { to } 51 \cdot 8) \\
69.8(64.2 \text { to } 75 \cdot 4)\end{array}$ & $\begin{array}{r}66 \\
70 \\
59 \\
171\end{array}$ & $\begin{array}{l}19.9(14 \cdot 1 \text { to } 25 \cdot 7) \\
19.7(14.2 \text { to } 25 \cdot 2) \\
18.6(12.8 \text { to } 24.3) \\
34.1(28.0 \text { to } 40 \cdot 2)\end{array}$ \\
\hline \multicolumn{5}{|l|}{ Educational level $\dagger$} \\
\hline $\begin{array}{l}\leqslant \mathrm{HS} \\
>\mathrm{HS} \text { and }<\mathrm{CG} \\
\mathrm{CG} \\
\geqslant \mathrm{PG}\end{array}$ & $\begin{array}{l}189 \\
249 \\
181 \\
193\end{array}$ & $\begin{array}{l}38 \cdot 8(32 \cdot 8 \text { to } 44 \cdot 8) \\
47 \cdot 4(41 \cdot 2 \text { to } 53 \cdot 5) \\
61 \cdot 8(53.8 \text { to } 69 \cdot 8) \\
67.9(60 \cdot 1 \text { to } 75 \cdot 8)\end{array}$ & $\begin{array}{r}110 \\
97 \\
96 \\
105\end{array}$ & $\begin{array}{l}22.3(17.5 \text { to } 27.2) \\
16.9(12.7 \text { to } 21.1) \\
34.1(26.0 \text { to } 42.3) \\
37.9(29.7 \text { to } 46.1)\end{array}$ \\
\hline \multicolumn{5}{|l|}{ Census region } \\
\hline $\begin{array}{l}\text { South } \\
\text { West } \\
\text { Northeast } \\
\text { Midwest }\end{array}$ & $\begin{array}{l}254 \\
255 \\
182 \\
126\end{array}$ & $\begin{array}{l}39.3(34.0 \text { to } 44.5) \\
68.8(62.0 \text { to } 75.6) \\
71.4(63.6 \text { to } 79.1) \\
33.9(27.2 \text { to } 40.6)\end{array}$ & $\begin{array}{r}103 \\
145 \\
118 \\
44\end{array}$ & $\begin{array}{l}16.6(12.7 \text { to } 20.5) \\
37.6(30.7 \text { to } 44.6) \\
44.7(36.4 \text { to } 53.0) \\
11.2(6.6 \text { to } 15.7)\end{array}$ \\
\hline
\end{tabular}

*Users = those reported to 'always' wear a helmet while bicycling.
tHighest educational level achieved in the household (HS = high school, CG = college graduate, PG = postgraduate).

PG = postgraduate). All associations were significant for own
at $\mathrm{p}<0.01$, except for sex of child.

Rows within a characteristic may not add to total because of missing data. 'no' ('don't know' = three children to riding, three to helmet owning, and 16 to helmet wearing; refusals = one, zero, and zero children, respectively). Only reported 'always use' of a helmet was counted as 'use' for the purposes of analysis.

For one randomly selected child, the respondent was asked if the child had seen or visited a physician or nurse during the preceding 12 months. If yes, respondents were asked if, during these visits, anyone gave the child or family member any written information or spoke to them about bicycle safety helmets. Responses of 'don't know' were considered as 'no'.

Data were weighted to provide national estimates and percentages. Household weights combine a sampling weight (the inverse of the probability of selection of the study unit) and a ratio adjustment (the ratio of the March 1994 Current Population Survey (CPS) number of households to the study estimates by census region and location in a metropolitan statistical area). Data on each child in the household was further weighted to reflect the March 1994 CPS estimates for the relevent age-sex-race group. In effect, the ratio adjustment procedure scales up the weights of children in a particular age-sex-race group in an area of the country to fully represent all such similar children in that area.

To account for the complex survey design, we used SUDAAN ${ }^{15}$ software for the statistical analysis of correlated data. This software package allowed us to obtain estimates using the proper design parameters and compute appropriate standard errors of these estimates. Failure to account for the complex survey design may result in an underestimate of the variance and a subsequent overestimate of the significance. Using SUDAAN, we generated weighted estimates and $95 \%$ confidence intervals $(\mathrm{CI})$ for the American population. The $\log$-likelihood $\chi^{2}$ test in SUDAAN assessed independence between our outcomes (helmet ownership and use) and selected demographic characteristics of our study population. To provide adjusted estimates of univariately significant predictor variables for helmet ownership and use, we conducted logistic regression in SUDAAN. Because income had so many missing values, and because income and educational level often are related, we used highest educational level in the household in our modeling procedures. We used the adjusted Wald-F test to assess statistical significance of variables in our model.

\section{Results}

Interviews were completed for 5238 households (response rate $=5238$ completed interviews/[5238 completed interviews +3630 refusals +474 incomplete interviews $]=$ $56.1 \%$ ). Of these 5328 households, 1490 contained one or more children aged 5-14 years, for a total of 2343 children in this age group.

Of these 2343 children, 1645 (weighted $72.7 \%$ ) were reported to have ridden a bicycle in the preceding month, that is, an estimated 
West

Ownership $=68 \cdot 8 \%$
Use always $=37 \cdot 6 \%$
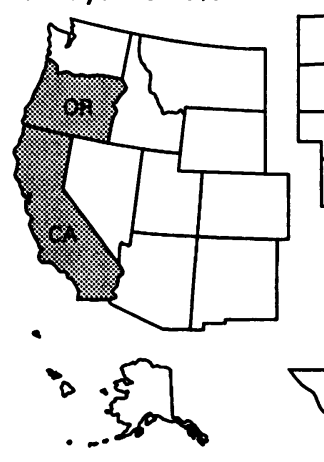

Midwest

Ownership $=33.9 \%$

Use always $=11 \cdot 2 \%$

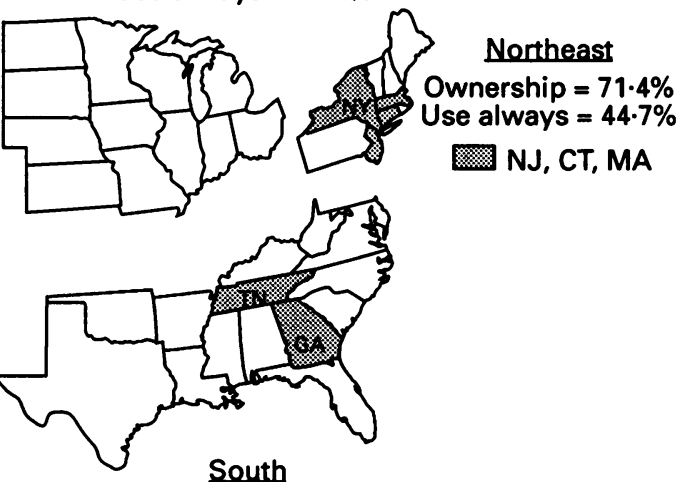

Ownership $=33.9 \%$

Use always $=16 \cdot 6 \%$

\section{Statewide mandatory helmet use law in effect in 1994}

Bicycle helmet ownership and use among children 5-14 years old, by census region, in the $U S$ in 1994 (CA=California, $C T=$ Connecticut, $G A=$ Georgia, $M A=$ Massachusetts, $N \mathcal{F}=$ New fersey, $N Y=$ New York, OR=Oregon, $T N=$ Tennessee).

Table 3 Top four adult reported reasons for American child bicyclists aged 5-14 years not owning or wearing a helmet, 1994

\begin{tabular}{lll}
\hline & $\begin{array}{l}\text { Unweighted No } \\
\text { of riders } \\
(n=1645)\end{array}$ & $\begin{array}{l}\text { Weighted \% } \\
\text { of riders }\end{array}$ \\
\hline Don't own helmet & 828 & $49 \cdot 8$ \\
Low risk & 251 & $14 \cdot 2$ \\
Never considered & 178 & $11 \cdot 0$ \\
Won't wear & 71 & $4 \cdot 3$ \\
Cost & 71 & $4 \cdot 2$ \\
Helmet owners & 817 & $50 \cdot 2$ \\
Always and $>50 \%$ users & 538 & $32 \cdot 4$ \\
$\leqslant 50 \%$ of time users $\dagger$ & 279 & $17 \cdot 8$ \\
Low risk & 62 & $4 \cdot 4$ \\
Child won't wear & 55 & $3 \cdot 5$ \\
Technical issues $\ddagger$ & 40 & $2 \cdot 3$ \\
Peer concerns & 36 & $2 \cdot 2$
\end{tabular}

« Responses $=$ helmet not necessary, child is infrequent rider, or child only rides in safe areas.

$\dagger$ Reasons were only asked for bicyclists reported to use helmets

half the time or less.

$\ddagger$ Responses $=$ uncomfortable, fit problem, helmet damaged or lost, interferes with riding.

Table 4 Relationship between selected characteristics and the likelihood of bicycle helmet ownership and use, US 1994

\begin{tabular}{|c|c|c|}
\hline Characteristic $^{\star}$ & $\begin{array}{l}\text { For helmet owning } \dagger \\
\text { odds ratio }{ }^{\star}(95 \% \mathrm{CI})\end{array}$ & $\begin{array}{l}\text { For helmet wearing } \ddagger \\
\text { odds ratio }{ }^{\star}(95 \% \text { CI })\end{array}$ \\
\hline \multicolumn{3}{|l|}{ Age (years) } \\
\hline $\begin{array}{l}5-9 \\
10-14\end{array}$ & 2.02 (1.58 to 2.57$)$ & 2.31 ( 1.73 to 3.10$)$ \\
\hline \multicolumn{3}{|r|}{1.00 (rererent) } \\
\hline Boy & $\begin{array}{l}1.22(0.96 \text { to } 1.57) \\
1.00 \text { (referent) }\end{array}$ & $\begin{array}{l}1.00 \text { (0.75 to } 1.33) \\
1.00 \text { (referent) }\end{array}$ \\
\hline \multicolumn{3}{|l|}{ Educational level§ } \\
\hline $\begin{array}{l}\geqslant \mathrm{PG} \\
\mathrm{CG} \\
>\mathrm{HS} \text { and }<\mathrm{CG}\end{array}$ & $\begin{array}{l}3.94(2.47 \text { to } 6.31) \\
2.86(1.79 \text { to } 4.58) \\
1.51 \text { (1.04 to } 2 \cdot 18) \\
1.00 \text { (referent) }\end{array}$ & $\begin{array}{l}2.40(1.48 \text { to } 3.89) \\
1.90(1.17 \text { to } 3.10) \\
0.69 \text { (0.45 to } 1.06) \\
1.00 \text { (referent) }\end{array}$ \\
\hline \multicolumn{3}{|l|}{ Census region } \\
\hline $\begin{array}{l}\text { Northeast } \\
\text { West } \\
\text { Midwest } \\
\text { South }\end{array}$ & $\begin{array}{l}4.18(2.60 \text { to } 6.72) \\
3.76(2.49 \text { to } 5.67) \\
0.84(0.56 \text { to } 1.24)\end{array}$ & $\begin{array}{l}4.43(2.80 \text { to } 7.00) \\
3.58(2.32 \text { to } 5.52) \\
0.70(0.40 \text { to } 1.22)\end{array}$ \\
\hline South & 1.00 (referer & 1.00 (referen \\
\hline
\end{tabular}

*Odds ratios are relative to the referent group after adjusting for all other factors in the model. Referent groups chosen on the basis of lowest percent of bicyclists.

†All variables significant at $p=0.001$ except for sex of child $(p=0.107)$

$\ddagger$ Helmet wearing = 'always' use. All variables significant at $p<0.001$ except for sex of child $(\mathrm{p}=0.992)$.

$\S$ Highest educational level achieved in the household (HS = high school, CG = college graduate, $\mathrm{PG}=$ postgraduate).

$27 \cdot 7$ million child bicyclists. Characteristics associated with bicycle riding were age and sex of child, household income, and census region (table 1). Helmets were reported owned by 817 (weighted $50.2 \%$ ) riders (table 2 ). Characteristics associated with ownership were age and sex of child, household income, highest educational level in the household, and census region (table 2, figure). Among all riders, reported helmet 'always' use was $25.0 \%$ (table 2 ). Rider characteristics associated with 'always' use were lower age of child, higher household income, higher educational level, and census region (table 2, figure). The most frequently offered reason for not owning, or wearing a helmet more often, was low perceived risk (table 3).

Multivariable modeling suggested that the strongest predictors of both helmet owning and helmet wearing were location in the Northeast or West, aged 5-9 years old, and higher educational achievement within the household (table 4).

Among 706 child bicyclists who had been seen by a health care provider in the preceding 12 months, 138 had been counseled to wear a bicycle helmet and 66 (weighted $43.9 \%$ ) were reported to comply. By contrast, among 568 seen by a provider but not counseled to wear a helmet, 109 (weighted 19.1\%) were reported always wearing a helmet $(p<0.001)$.

Another perspective comes from data on seat belt use and bicycle helmet wearing. Among 1610 child bicyclists with data on seat belt use and bicycle helmet wearing, the weighted 'always' helmet use rate was $31.4 \%$ among 1212 children always using a seat belt compared with $7 \cdot 1 \%$ helmet use among 398 children not always wearing a seat belt $(\mathrm{p}<0.001)$.

\section{Discussion}

Despite a variety of community efforts to increase the use of bicycle helmets among children, ${ }^{16}$ helmet wearing is still not typical behavior among child bicyclists in the US, especially older children. There is no single reason why helmet ownership and use is not more popular; however, 'low perceived risk' and 'never considering the issue' were the most frequently offered reasons for non-use in this and in some other surveys. ${ }^{13}$ While direct interviewing of children may reveal somewhat different reasons for non-use (for example peer pressure, unattractiveness of helmets), ${ }^{17} 18$ our results suggest that educational efforts targeted at parents and health care providers may provide some additional impetus for behavior change, especially for younger children who are typically under more 'parental control' than older children.

Clearly, helmet ownership is a necessary (but not sufficient) condition for helmet use. Our finding that helmet owernship and use is associated with household income and age of the child, confirms the findings of other telephone surveys. ${ }^{1319}$ While discount or rebate programs for helmets have been suggested as a means to increase use among low income child- 
ren, it is not clear that this approach is consistently effective. ${ }^{2021}$

From our data, it appeared that about half of helmet owners always use them and this proportion was similar across income groups (table 2). This estimated 'always use' proportion among owners is lower than one study estimated $(83 \%)^{19}$ but roughly the same as in two other studies. ${ }^{1322}$ An accurate estimate of the ratio of use to ownership might provide direction in developing new approaches to evaluating community bicycle helmet promotion programs.

The strong association between prior counseling by a health care provider and the likelihood of helmet use was intriguing. Studies have suggested that counseling in such settings may influence behavior ${ }^{23}$ and helmet use. ${ }^{24}$

Interestingly, although boys appear at higher risk of bicycle related head injury than girls, ${ }^{425}$ this outcome does not appear to be due to differences in helmet ownership or use rates. ${ }^{13}$

This survey has a number of limitations. First, the response rate of $56 \%$ is relatively low for a telephone survey. Although a comparison of respondent households with census data suggests that this survey includes a fairly representative cross section of the population (JJ Sacks, written communication, 1995), average income and educational attainment is higher than in the general population, as is true for most telephone surveys. The underrepresentation of lower income households is particularly problematic for this study, however, because helmet ownership and use appears associated with household income.

Another limitation is that we used proxy reports about childhood behavior. Adults may know helmet ownership status more accurately than actual use; the accuracy of use reports may also depend on the child's age. Recent studies, however, suggest that such proxy reports among injured child bicyclists accurately reflect helmet use noted in medical records (Circumstances and severity of bicycle injuries: a report to the Snell Memorial Foundation. DC Thompson, FP Rivara, RS Thompson, unpublished manuscript). Recent studies also suggest that adults may over-report childhood helmet use relative to what is observed in the community or at schools. ${ }^{26}$ If that is the case here, then helmet use is even lower than the $25 \%$ we have estimated.

Conversely, because we defined use as 'always' use, we may have underestimated use. Some of those classified as non-users may wear helmets some of the time. However, studies of self reported seat belt use and observed behavior, ${ }^{27}$ and studies comparing aggregated parental reports on bicycle helmet use to observations of children, ${ }^{26}$ suggest that only classifying 'always' users as users may better emulate what is observed.

\section{Implications for prevention}

Medical care for bicycle related injuries in the US costs an estimated $\$ 8$ billion dollars per year. ${ }^{28}$ Raising childhood helmet usage could prevent many deaths and injuries and result in substantial cost savings. ${ }^{425}$ Bicycle helmet use laws appear effective in increasing helmet use among children. ${ }^{161926} \mathrm{It}$ is of interest, therefore, that among census regions of the US, those with the highest proportion of states with statewide helmet use laws in 1994 also had the highest proportion of helmet use among children (figure). In the Northeast, for example, four of nine states has such laws in 1994 and $71.4 \%$ and $44.7 \%$ of child bicyclists owned and used helmets, respectively. In the Midwest, no state had such laws, and helmet ownership and use were the lowest at $33.9 \%$ and $11.2 \%$, respectively. To meet the Healthy People 2000 objective of $50 \%$ of bicyclists wearing helmets, ${ }^{12}$ use among children will have to double. While there appears to have been a doubling in use from $1991,{ }^{13}$ concerted and increased efforts to promote the wearing of bicycle helmets by children appear necessary. In the health care setting, counseling children and parents of bicycle riding children ${ }^{29}$ may be a useful adjunct to other efforts.

The following are members of the ICARIS project: Principal investigator: Jeffrey J Sacks, MD, MPH. Project core group: Barbara Houston, Marcie-jo Kresnow, MS, Joann M O'Neil, BA; and Suzanne M Smith, MD, MPH, of NCIPC; James BA; and Suzanne $M$ Smith, MD, MPH, of NCIPC; James
Hersey, PhD; Rick Williams, PhD, and Aiman Zeid, MS, of Hersey, PhD; Rick Williams, PhD, and Aiman Zeid, MS, of
Battelle; Sherry Marcy, MPH, and Deborah J Zivan, BA, of Battelle; Sherry Marcy, MPH, and Deborah J Zivan, BA, of
DataStat. Project associates: Christine M Branche-Dorsey, DataStat. Project associates: Christine M Branche-Dorsey,
PhD; Peter Briss, MD; Terence Chorba MD, MPH; Alex PhD; Peter Briss, MD; Terence Chorba MD, MPH; Alex
Crosby, MD, MPH; Yvette Davis, VMD, MPH; Jennifer Friday, PhD; Arlene Greenspan, Dr PH, PT; James Mercy, PhD; Phil McClain, MS; Julie Russell, PhD; Lloyd Potter, PhD, MPH; and Kenneth E Powell, MD, MPH, of NCIPC; Thomas Matte, MD, MPH, of National Center for Environmental Health.

1 Fife D, Davis J, Tate L, Wells JK, Mohan D, Williams A. Fatal injuries to bicyclists: the experience of Dade County, Florida. $\mathcal{F}$ Trauma 1983; 23: 745-55.

2 Nakayama DK, Gardner MJ, Roders KD. Disability from bicycle-related injuries in children. $\mathcal{F}$ Trauma 1990; 30: 1390-4.

3 Spence LJ, Dykes EH, Bohn DJ, Wesson DE. Fatal bicycle accidents in children: a plea for prevention. $\mathcal{F}$ Pediatr Surg 1993; 28: 214-6

4 Sosin DM, Sacks JJ, Webb KW. Pediatric head injuries and deaths from bicycling, United States. Pediatrics 1996; 98: (in press).

5 Silverberg D, Meer A, Silvinger E, Gross M, Feldman S Head injuries after serious bicycle accidents. Eur $\mathfrak{f}$ Epidemiol 1992; 8: 826-31.

6 O'Rourke NA, Costello F, Yelland JDN, Stewart GG. Head injuries to children riding bicycles. Med $\mathcal{F}$ Aust 1987; 146: 619-21.

7 Olkkonen S, Lahdenranta U, Slätis P, Honkanen R. Bicycle accidents often cause disability. Scand $\mathcal{F}$ Soc Med 1993; 21: 98-106.

8 Thompson RS, Rivara FP, Thompson DC. A case-control study of the effectiveness of bicycle safety helmets. $N$ Engl 千 Med 1989; 320: 1361-7.

9 Maimaris C, Summers CL, Browning C, Palmer CR. Injury patterns in cyclists attending an accident and emergency department: a comparison of helmet wearers and nondepartment: a comparison of helm

10 McDermott FT, Lane JC, Brazenor GA, Debney EA. The effectiveness of bicyclist helmets: a study of 1710 casualeffectiveness of bicyclist helmets:

11 Thomas S, Acton C, Nixon J, Battistutta D, Pitt WR, Clark $R$. Effectiveness of bicycle helmets in preventing head injury in children: case-control study. BMF 1994; 308 173-6.

2 Public Health Service. Healthy people 2000: national healt promotion and disease prevention objectives. Washington (DC): US Department of Health and Human Services, PHS; 1991. DHHS publication No (PHS) 91-50212.

13 Rodgers GB. Bicycle helmet use patterns among children. Pediatrics 1996; 97: 166-73.

14 Kann L, Warren CW, Harris WA, et al. Youth risk behavio surveillance, United States, 1993. CDC Surveillance Summaries. 24 march 1995. MMWR 1995; 44 (No SS-1)

15 Shah BV. SUDAAN survey data analysis software. Release 6.34. Research Triangle Park, NC: Research Triangle Institute, 1993 .

16 Centers for Disease Control and Prevention. Injury-contro recommendations: bicycle helmets. MMWR 1995; 44 (RR-1): 1-17. 
17 Howland J, Sargent J, Weitzman M, et al. Barriers to bicycle helmet use among children. Am $\mathcal{f}$ Dis Child 1989; 143: $741-4$.

18 DiGuiseppi CG, Rivara FP, Koepsell TD. Attitudes towards bicycle helmet ownership and use by school age children. Am $\mathcal{F}$ Dis Child 1990; 144: 83-6.

19 Schieber RA, Kresnow M, Sacks JJ, et al. Effect of a state law on reported bicycle helmet ownership and use. Arch Pediatr Adolesc Med 1996; 150: 707-12.

20 Parkin PC, Hu X, Spence L, et al. Evaluation of a subsidy program to increase bicycle helmet use by children of low program to increase bicycle helmet use by child
income families. Pediatrics 1995; 96: 283-7.

21 Winn GL, Jones DF, Bonk CJ. Taking it to the streets. Helmet use and bicycle safety as components of inner city youth development. Clin Pediatr (Phila) 1992; 31: $672-7$.

$22 \mathrm{Hu}$ X, Wesson DE, Parkin PC, Chipman ML, Spence LJ Current bicycle helmet ownership, use, and related factors among school-aged children in metropolitan Toronto. Can f Public Health 1994; 85: 121-4.

23 Bass J, Christoffel K, Widome M, et al. Childhood injury prevention counseling in primary care settings: a critical review of the literature. Pediatrics 1993; 92: 544-50.
24 Schneider ML, Ituarte $P$, Stokols D. Evaluation of a community bicycle helmet promotion campaign: what works and why. American fournal of Health Promotion 1993; 7: 281-7.

25 Sacks JJ, Holmgreen P, Smith SM, Sosin DM. Bicycleassociated head injuries and deaths in the United States from 1984 through 1988: how many are peventable? from 1984 through 1988:

$26 \mathrm{Ni} \mathrm{H}$, Sacks JJ, Curtis L, Cieslak PR, Hedberg K. Evaluation of a statewide bicycle helmet law via multiple measures of helmet use. Arch Pediatr Adolesc Med 1996 (in press).

27 Nelson DE. Validity of self reported data on injury prevention behavior: lessons from observational and self reported surveys of safety belt use in the US. Injury Prevention 1996; 2: 67-9.

28 Rodgers GB; Tinsworth DK, Polen C, et al. Bicycle use and hazard patterns in the United States. Washington, DC: US Consumer Product Safety Commission, June 1994.

29 Committee on Injury and Poison Prevention. Office-based counseling for injury prevention. Pediatrics 1994; 94: 566-7.

joined the Dunedin Multidisciplinary Health and Development Research Unit (DMHDRU) in 1984. The DMHDRU is well known for its research on the injury experience of a large New Zealand birth cohort. His involvement with the cohort began when the members were 13 years of age.

In 1990, he co-founded the IPRU and has been involved in developing the IRPU's access to the national injury mortality and morbidity data bases that have become the foundation for much of its research on both intentional and unintentional injury. In the area of childhood and adolescent injury he has been involved in projects on school, motor vehicle, motorcycle, bicycle, equestrian, architectural glass, trampoline and playground injuries, and child abuse.

Dr Chalmers has responsibility for the IPRU's research on sport and recreational injury and in this capacity has enjoyed the opportunity to be involved in research at a number of levels, including descriptive, analytic, and evaluation studies. He is particularly proud of the IPRU's work in the area of playground equipment related injury and represents New Zealand on the Playground Equipment Committee of Standards Australia. He is a member of the New Zealand Water Safety Council's Consultative Group on the Fencing of Swimming Pools, and is a Scientific Officer and Committee Member for the Health Research Council of New Zealand. 